\title{
"The land belonged to Nepal but the people belonged to Tibet": Overlapping sovereignties and mobility in the Limi Valley borderland
}

(Single author)

Emily T. Yeh

Professor of Geography, University of Colorado Boulder

Address:

Department of Geography

CU Boulder Campus Box 260

Boulder CO 80309-0260

USA

emily.yeh@colorado.edu

303-492-5438

Keywords

Tibet, Nepal, Sovereignty, Mobility, Borderlands

\section{$\underline{\text { Acknowledgements }}$}

I am grateful for the opportunity to undertake the fieldwork, which was provided by Ashok Gurung at The New School's India China Institute with funding from the Luce Foundation. I also thank Tsewang Lama and Martin Saxer for their insights about Limi; Yonten Gyato (Sagar Lama) for his assistance in follow-up research; Astrid Hovden for sharing her dissertation with me; Mark Henderson for cartography; and Jason Cons, Jennifer Fluri, Andrew Grant, Phurwa Gurung, Galen Murton, and three anonymous reviewers for helpful comments on earlier drafts. 


\begin{abstract}
Recent scholarship on the lived experiences of borderlands has foregrounded and theorized the pervasiveness of anxiety, violence, and lawlessness. While useful, these do not capture all of the ways in which borderland residents relate to diverse constellations of power. This paper examines the China (Tibet Autonomous Region) - Nepal borderland through the case of the Limi Valley, in the northwest corner of Nepal's Humla district. Before 1959, the valley was considered part of Nepalese territory, yet its residents belonged administratively to the Tibetan government, an arrangement at odds with contemporary understandings of state territorial sovereignty. The non-postcolonial state formations of Nepal and China have created their own specific forms of border citizenship and overlapping sovereignties. The article shows how multiple sovereignties can stretch beyond state borders in unexpected ways by tracing how Limi Valley residents negotiate overlapping sovereignties of the Nepali and Chinese states, as well as the non-state sovereignty of the Tibetan government-in-exile. Furthermore, it demonstrates that these in turn overlap with a form of social sovereignty grounded in the community's body of laws, codes, and practices, which are at once a historically sedimented trace of Limi's governance before the nation-state, and a product of navigating political transformations. However, challenges to this social sovereignty, expressed through the idiom of statist law, have recently emerged. Whereas states typically exert sovereign power in borderlands by restricting mobility, some Limi villagers now selectively invoke state sovereignty through law to enable greater mobility.
\end{abstract}

Keywords

Tibet, Nepal, Sovereignty, Mobility, Borderlands 


\section{'The land belonged to Nepal but the people belonged to Tibet': Overlapping sovereignties and mobility in the Limi Valley borderland}

\section{Introduction}

A high, narrow valley in upper Humla District of northwest Nepal, Limi is cut off from the rest of the country for five to six months each year by the 4940-meter Nyalu pass. The three villages of the valley, Waltse, Dzang, and Til, are not connected by road to the district capital of Simikot, itself not yet connected by road to the rest of Nepal. From Simikot to the closest village in Limi is a four to five day journey by foot, and until the establishment of a satellite phone in 2010, the nearest phone was a two-day walk across the border in China's Tibet Autonomous Region (TAR). However, the absence of motorable roads and telephone lines does not mean a lack of connectivity. Like all places, infrastructurally remote and otherwise, Limi is constituted by social relations at multiple scales, and connected to other places through differentiated mobilities of people, material goods, ideas, and practices (Massey 1991; Tsing 1993). Indeed, the people of Limi have been highly mobile for centuries. As national borders have crossed their lines of movement, and as the uneven dynamics of global capitalism shift centres of economic power, their mobility has become increasingly transnational. Many Limi community members now spend their summers engaged in labour or trade in the nearby town of Burang (Chinese: Pulan, Nepali: Taklakot), in what is now China's TAR, and their winters trading, going on religious pilgrimage, and visiting children in boarding schools in northern India and in Kathmandu (see Map 1. and Map 2.).

Until 1961, the Limi Valley defied standard contemporary understandings of state territorial sovereignty. As villagers commonly explain it, 'the people belonged to Tibet' whereas 'the land belonged to Nepal.' Even today, though the people of Limi are now Nepali citizens, 
the borderland valley troubles what Agnew (1994) has termed the 'territorial trap,' the flawed but persistent assumptions of state territorial boundaries as timeless, a priori containers of society. As political geographers have noted, borderlands are particularly good places to see beyond Westphalian blinders of national belonging, citizenship, and territorial integrity. While borders are key sites of the intense performance of sovereign authority, borderlands are simultaneously places where the sovereign power of the bounding state is often incomplete and experienced as a ، “distant glow” rather than a permanent presence' (Jones 2009, 2012; Korf and Raeymaekers 2013, 12).

In this article, I follow calls by political geographers and anthropologists to investigate the 'lived experiences of people inhabiting borderlands and their multiple identifications, spatial logics and relations developed in interaction with diverse political constellations' (Korf and Raeymaekers 2013, 6; also Gellner 2013; Jones 2012; Megoran 2006; Reeves 2014; Wilson and Donnan 1998). Experiences of everyday life in the borderlands belie the assumed coterminosity of nation, state, and territory. In the Ferghana Valley, for example, Megoran (2006) traces the ambiguous and sometimes absurd situations the new border regime produced, such as neighbours living on one street suddenly separated into two countries by a barbed wire fence. Also in the Ferghana Valley, Reeves (2014) foregrounds how residents experience the spatialization of the state at newly created post-Soviet borders, and interrogates the contentious and contested work that must be done to translate the spatial imaginary of the discrete nation-state into concrete arrangements on the ground. State power in these borderlands functions through 'sporadic assertions of sovereignty' made by strongmen who claim to embody state authority.

Like the Ferghana Valley, the India-Bangladesh enclaves have been particularly productive sites for recent research on borders, particularly in relation to the question of 
sovereignty (Cons 2016; Dunn and Cons 2014; Jones 2009, 2012; Schendel 2002; Shewly 2013, 2015). Focusing on the failure of both India and Bangladesh to institutionalize sovereignty and its concomitant legal framework in the enclaves, Shewly $(2013,2015)$ argues that they can be described as what Giorgio Agamben (1998) calls 'spaces of exception.' Abandonment by their home countries and exclusion from rights of citizenship produce enclave residents as potential bare life, differentially exposing them to gendered violence. Jones (2009), too, finds that the India-Bangladesh borderlands can be characterized as spaces of exception, where extralegal violence against Muslims is deployed with impunity. However, he notes that it is border guards, whom he conceptualizes following Butler $(2004,56)$ as 'petty sovereigns,' who have the authority to decide on the exception. Because these actors frequently undermine state goals even while claiming state authority, Jones (2012) argues that the state of exception literature overstates the pervasiveness of state sovereign power. Furthermore, the everyday practices of borderland residents often cannot be properly understood through the binary of domination and resistance; instead, he argues, borderlands are 'spaces of refusal' where there is 'the possibility that different frameworks outside sovereign state territoriality could be created, even though these alternatives are not being pursued yet' (Jones 2012, 687-88).

Also focusing on the India-Bangladesh enclaves, Jason Cons takes to task the concepts of 'state of exception' and bare life that scholars, following Agamben, have adopted to discuss borderlands, for producing simplified binaries that reproduce state mystifications (2016). Rather than a uniform, monolithic sovereign power, wielded by a sovereign who derives power through the creation of a state of exception, Dunn and Cons show that life in contested borders and camps is more often characterized by 'multiple, partial, and overlapping decisions about establishing order and control' $(2014,95)$. Rather than 'space of exception,' Cons (2016) proposes the 
analytic of 'sensitive space' as a more supple and productive alternative for describing the territorial anxieties that pervade the Indian-Bangladesh enclaves.

Compared to the cases discussed above, the Sino-Nepali borderlands in general, and Limi in particular, are neither particularly violent nor anxious. Though the sovereign authority of the Nepali state is largely absent, the people in Limi do not exist as bare life. The border itself is not contested, yet overlapping sovereignties are still at play. Indeed, as Shneiderman $(2013,27)$ has argued, the 1400 kilometre-long border between Nepal and China's TAR is characterized by border citizens 'whose very presence compels the two states in question to formally recognize their overlapping sovereignty in the border zone.' Thus, understanding Limi as a borderland requires a more capacious understanding of sovereignty than one grounded in the sovereign exception.

\section{Non-state sovereignty}

Though the overlapping sovereignties of the Chinese and Nepalese states are important, they do not fully explain governance and authority over a range of everyday actions in Limi ranging from land use to mobility to taxation. Thus, I argue that it is also necessary to consider non-state forms of sovereignty. Shifting the study of sovereignty from the formal organizing principle of the international legal system to questions about the capacity to exert authority and govern, recent scholarship in political geography and beyond has demonstrated that sovereignty is not the sole possession of states (Korf et al. 2018; Latham 2000; Moore 2005). Theorizations that complicate the idea of state sovereignty have been motivated in part by globalization and the emergence of transnational finance (Agnew 2005; Latham 2000) as well as by the recognition of the need to take seriously the de facto sovereignty of non-state polities (McConnell 2009, 2010). 
Another focus has been on colonial and postcolonial non-state sovereignties.

Summarizing this body of work, Hansen and Stepputat $(2006,297)$ argue that while the effective legal sovereignty over territory and people claimed by modern states has always been an unattainable ideal, it is 'particularly tenuous in many postcolonial societies in which sovereign power was historically fragmented and distributed among many, mostly informal but effective forms of local authority.' Research on non-state sovereignties in the postcolonial Global South, particularly in border regions, has thus tended to focus on 'petty sovereigns' or 'de facto sovereign actors,' such as local strongmen, vigilantes, insurgents, illegal networks, gangs, and warlords (Hansen and Stepputat 2006; Korf and Raeymaekers 2013, 20; Korf et al. 2018; Zeller 2013). These relational terms reflect the conventional identification of 'the law' with the state, a point to which I will return below. Though not attached to the state, sovereignty in these formulations is still seen as a condition of agency.

In contrast, I adopt Robert Latham's theorization of sovereignty, understood as 'the existence of a highest or supreme power over a set of peoples, things or places,' as something that is not a characteristic of agents but rather of structures, such as bodies of law, code, or principles $(2000,2)$. Latham reminds us that the association of sovereignty with social structures precedes the Westphalian political tradition. Despite frequent efforts in political theory to locate sovereignty in an agency, such as a king or the people, that location is itself predicated upon the existence of "various codes and structures of relation that made it possible to be supreme in one domain of life' (Latham 2000, 6).

Latham uses the term 'social sovereignty' to expand sovereignty beyond the state to other forms of social organization, and to signify that 'what is at stake in sovereignty is not the status of an agent...but of a body of relations that shape spheres of life operating within or even across 
state boundaries' $(2000,3)$. States are indeed agents of social sovereignty, but not the only ones. Latham develops this concept to theorize global financial networks and markets, which depend on a restricted set of agents (experts, investors, corporations, states) to reproduce and adhere to sets of codes, practices, and rules, such as on currency transactions and financial instruments. Rather than simply something that limits the possibility of (state) sovereignty, Latham argues, global financial markets should be viewed as their own form of (social) sovereignty. In this sense, social sovereignty resembles Agnew's $(2005,437)$ view of 'de facto sovereignty' as 'all there is.'

Though Latham develops social sovereignty as a concept to address domains of social existence such as transboundary capital markets, he suggests that it can also 'emerge around the unique rules, laws, institutions, and customs of relatively self-governing groups living within existing state boundaries' (Latham 2000, 14). Social sovereignty can clearly emerge among groups that identify as indigenous, as well as others, typically organized around identity and land (Gazit and Latham 2014).

I argue for the importance of examining the social sovereignty of the Limi community, expressed not through a singular powerful agent but rather through laws and practices that are at once a historically sedimented trace of Limi's experiences of governance before the nation-state, and a product of navigating political transformations. Whereas Jones (2012, 687-88) finds that alternatives to state sovereignty are 'not being pursued yet' in the Bangladesh-India borderlands, Limi provides an example of a non-state, social sovereignty that is already in practice. The social sovereignty that I analyse below is not entirely unique; similar forms can be found in other Himalayan borderland communities, though they have not been theorized in these terms (e.g. Childs and Choedup 2018; Ramble 2008) nor discussed in the political geography literature on borders. Tracing social sovereignty in Limi over time in relation to shifting constellations of 
power and authority, as well as exploring current challenges to it, this article provides a concrete example of overlapping state and non-state sovereignties in the Himalayan borderlands.

Although the term 'borderland' suggests a fixed location, issues of mobility, migration, and transnationalism loom large (Cunningham and Heman 2004; Saxer, Rippa, and Horstmann 2018). Regulation and control of mobility across borders is of course a key means of asserting state sovereignty. At the same time, borderland residents agentively use borders as resources for their livelihoods (Chan and Womack 2016; Korf and Raeymaekers 2013; Wallrapp, Faust, and Keck 2019). Tracking the relationship between mobility and sovereignty, this article examines how political-economic transformations in both China and Nepal, along with both states' attempts to control informal mobility across the border, helped maintain social sovereignty by enabling Limi residents to perpetuate a ritual economy centred on a monastic institution. At the same time, further expanded mobility is now subjecting this social sovereignty to new challenges.

This analysis of the Limi Valley contributes to geographical studies of borderlands in several ways. Borderland studies in the Global South are significant given that Euro-American borderlands are still often taken as paradigmatic places from which to develop universalizing theories (Dean 2018; Gellner 2013). However, studies of borderlands in the Global South, and particularly in South Asia, have been dominated by the context of postcolonial state formation (Hansen and Stepputat 2006; Korf and Raeymaekers 2013). The historical trajectories of 'nonpostcolonial' state formation in both Nepal and China create their own specific forms of borderland citizenship (Des Chene 2007; Shneiderman 2013), and of overlapping sovereignties, as I explore here. Second, I expand the notion of overlapping border sovereignties to those beyond the state, and more specifically, argue that social sovereignty is a productive analytic, one that allows us to see alternatives to state sovereignty in practice. Third, I argue that the lived 
experience of the Limi Valley borderland is imbricated in contestations over law in relation to sovereignty and mobility. Not only does sovereignty shape mobility, but new forms of mobility also shape contestations over sovereignty.

This article is based on interviews with village leaders, several monks, and mostly middle-aged men and women from Waltse, Dzang, and Til. Initial interviews were conducted in Limi as part of the Sacred Himalaya Initiative of The New School's India China Institute in July 2016. I also conducted interviews with Limi labourers and traders in Burang, and Limiwas in Kathmandu in August 2016. Follow-up interviews were conducted in Limi in November 2016, in New York in April 2017, and in Kathmandu in April 2019. Finally, the article draws from key informant interviews from other residents of Humla, and from Astrid Hovden's (2016) dissertation on Limi. ${ }^{1}$ I turn first to a brief sketch of governance of the Limi Valley prior to the demarcation of the border in 1961, as this history is fundamental to understanding contemporary social sovereignty. Next, I discuss how the border demarcation transformed the mobility of the residents of Limi (whom I refer to with the Tibetan term 'Limiwas'), and how they have subsequently used the border as a resource to respond to changing economic fortunes on the two sides of the border. Following this, I examine Limiwas' border citizenship, developed in relation to both Nepalese and Chinese state sovereignties, and argue that Limiwas' growing economic dependence on China ironically draws on their Tibetan identity. Next I discuss the overlapping sovereignties of the Chinese and Nepali states as well as the Tibetan government-in-exile. The final section analyses the community's social sovereignty as a body of laws, codes, and practices that dictate taxes and residence, and how new forms of mobility are challenging these laws.

$<$ Map 1. around here $>$ 
$<$ Map 2. around here $>$

\section{Governance in Limi before the nation-state}

The Limi Valley was settled by people from Ngari (western Tibet) and Limiwas speak the same Tibetan dialect as is spoken in Burang. Since at least the thirteenth century, Limi residents paid a 'land tax' to the various kingdoms ruling what is now western Nepal, a practice that continued after the region's incorporation into Nepal in 1789 (Hovden 2013, 2016). However, because they were considered Tibetan, Limi villagers also paid a 'person tax' to the government in Burang District, which was incorporated in the seventeenth century into the Tibetan government based in Lhasa (Goldstein 1975). They paid taxes to Burang District, today the seat of Pulan County, Ngari (Chinese: Ali) Prefecture, TAR, as well as to three monasteries in Ngari. These included dried radishes and wooden utensils, and especially butter for butter lamps -- votive lamps that burn day and night in Tibetan monasteries.

Within the valley, Waltse Village is home to the eleventh-century Rinchenling Monastery, one of the oldest Tibetan Buddhist monasteries in Nepal. Initially a temple, it became a monastery of the Drigung Kagyu school of Tibetan Buddhism in the $15^{\text {th }}$ century. Two other Drigung Kagyu temples, later monasteries, were also established in Til and Dzang in the $13^{\text {th }}$ century; all three became branch monasteries of Gyangdrag Monastery, at the foot of Mount Kailash in Tibet (Hovden 2013, 2016). In the seventeenth century, the monasteries of Til and Dzang were merged with Rinchenling, an arrangement that persisted until a dispute over the monastic economy in the 1980 s led to their separation (ibid). Reincarnations of the lama associated with Rinchenling Monastery (Limi Tulku) have for at least the past four generations always been identified from one of two villages in Burang. 
Despite Rinchenling Monastery's association with Gyangdrag Monastery, the villagers themselves were the sponsors of its monastic economy. As Hovden (2013) meticulously documents, this was a heavy burden on the small community, and included compulsory ritual sponsorship, paying lease fees for the use of monastery land, the provision of labour to keep the monastery running, and a monk levy, the requirement that households send their second son to the monastery to become a monk when they reached the age of eight. In return for villagers' support, Rinchenling Monastery performs a variety of rituals to generate religious merit for them.

The distribution of both external and internal taxes and obligations were based on a tripartite social division within the community: (1) 'large households,' who claim to be direct descendants of the original landowning households and who are responsible for a full share of tax obligations; (2) 'small households,' siblings of direct descendants who have split off into their own households rather than join or remain in polyandrous households, and who are responsible for a half-share of taxes; and (3) 'woman alone' or female-headed households who have virtually no land and thus fewer tax obligations. This household stratification continues to structure social life in Limi today, as does the monk levy, in which large households with two sons and small households with three sons are required to send one (usually the second) son to become a monk at Rinchenling. Once common across Tibetan communities, the monk levy has been largely abandoned in other places, but persists in Limi.

Though Limi was under both Nepali and Tibetan jurisdiction for much of its history, Tibetan officials were more frequently involved in its affairs (Hovden 2016, 126). For the most part, however, four local hereditary leaders governed everyday life. These leaders negotiated with Nepali and Tibetan authorities, settled local disputes, wrote local legal documents, kept 
village archives, and made management decisions. However, these hereditary leaders did not govern the monastery, which had (and has) its own separate management system (Hovden 2016).

\section{Mobility, livelihoods, and the border}

In addition to cultivating land, Limiwas historically grazed yaks, sheep, and horses in the Limi Valley in the spring, summer, and fall, and brought them over to pastures south of Lake Manasarovar in what is now the TAR in the winter. Beyond pastoralism and agriculture, Limi residents, like those throughout Humla and much of the rest of the Himalayan borderlands, were also traders (Bauer 2004; Bishop 1990; Fürer-Haimendorf 1975; Murton 2017b; Spengen 2000). They brought rock salt down to lower regions of Nepal, and grains including wheat, barley, buckwheat, and rice up to Tibet. The trade also included wool, yak tails, wooden bowls, musk, timber, medicinal plants, spices, and a variety of manufactured goods (Saxer 2013). Trade was conducted in Burang as well as seasonal trade marts and commercial fairs that took place on both sides of the current international boundary. Terms of the salt-grain trade were very favourable for these traders, making upper Humla overall, including Limi, a place of moderate prosperity (Ross 1983).

In the 1950s, Chinese officials presented gifts of silver coins to local leaders in Limi to encourage them to become part of the newly established People's Republic of China, an invitation they rejected based on the results of a divination from their protector deity. In 1959, the failed uprising in Tibet led to the rapid and violent dismantling of the Tibetan government in Lhasa. The 1961 Sino-Nepal Boundary Treaty and the 1963 Border Protocol put both the people and land of the Limi Valley firmly within the territory of Nepal. They also closed all but six border crossings, including the Lapcha Shar crossing which led from Dzang to pastures on the 
shores of Lake Manasarovar, thus moving the closest crossing to the current Hilsa border, west of the Limi Valley (Saxer 2017).

The closing of the border was disruptive for communities across the entire Nepal-Tibet border, whose livelihoods had long depended upon both the salt-grain trade and transhumant pastoralism (Bauer 2004; Fisher 1990; Ross 1983). Formalizing an earlier 1956 'Agreement on Trade and other Related Matters,' the 1963 Boundary Protocol named 'border inhabitants' as a special category of person: 'Border inhabitants of the two countries may, within an area of thirty kilometres from the border, carry on the petty traditional trade on a barter basis' (Bauer 2004, 82; Saxer 2013, 37). However, the Protocol also called for the abolition of 'the existing practice of transfrontier pasturing by border inhabitants of both countries' (Bauer 2004, 82). Thus, across most of the border, winter pastures in Tibet were suddenly cut off, and many livestock died or were sold off soon after.

Limi was the one exception; the Limi community was allowed to use one pasture area near the shores of Lake Manasarovar, with the payment of a fee. However, this pasture was of much poorer quality than what they had used in the past, and the agreement had to be renegotiated every five years. By the mid-1970s, Limiwas were already quite cautious about investments into their herds (Goldstein 1974, 1975). After the last agreement expired and was not renewed by the Chinese side in 1991, many households sold off large portions of their livestock, and a few families used the cash to purchase houses in Kathmandu.

Trade, now restricted to the six official border crossings, was increasingly subject to new regulations by the Chinese state. Traders were no longer allowed to buy and sell directly to Tibetans, but instead were restricted to official Chinese stores in Burang. All commodities were weighed at the official depot and prices were set by the Chinese state, significantly reducing 
profit margins (Bishop 1990; Goldstein 1974; Ross 1983). Nevertheless, in most communities, income from trading declined more gradually than did cross-border grazing.

Like the rest of China during the period of high socialism and the Cultural Revolution, Burang stagnated economically and remained dependent on grain imported from Humla. However, this changed after China launched its Opening up and Reform policies in 1978, leading to the dismantling of communes, the implementation of the Household Responsibility System, and the emergence of a market economy. In the TAR, market reforms intensified and state subsidization for infrastructure projects increased in the mid-1990s following Deng Xiaoping's 1992 Southern Tour and the 1994 Third Work Forum on Tibet (Yeh 2013).

While Burang began to recover economically, a number of processes were accelerating the transformation of upper Humla district from relatively prosperous to impoverished and food insecure. These included the complete collapse of the salt trade as a result of the introduction of iodized salt from India to Nepal, a crackdown on illicit trade in animal skins, bones, and antiques, and the introduction of community forestry across Nepal (Saxer 2013). Whereas Burang residents sometimes came to Limi for access to food during China's period of high socialism, the situation now reversed. By the mid-1990s, some Limiwas began to work seasonally in Burang; women largely performed small jobs such as cleaning wool for local pastoralists, helping with the barley harvest, and weaving carpets. In other words, Limiwas began to use the border - and their ability to move across it - as a resource for their livelihoods in the context of the economic decline of Humla.

With the launching of China's Open up the West campaign in 2000 and increasingly intensive subsidization of the TAR economy, income opportunities for Limi dramatically increased. By the mid-2000s, many Limiwas were spending six months of the year, roughly 
April through October, in Burang doing what they call 'Chinese work' - construction of roads and buildings, as well as work in shops and restaurants. Daily wage labour rates in Burang are more than double what they can earn in Humla. Some Limiwas have learned Chinese, while others rely on Tibetan migrant labourers from Shigatse alongside whom they work, to translate between Tibetan and Chinese for them. These new economic resources, in turn, allow them to fulfil their local tax obligations that are central to the social sovereignty of the community, as I argue below, while also making them more subject to Chinese state sovereignty.

Like lay community members, Limi monks also use the border as an economic resource. Though they are required to reside at their monastery for seven months of the winter to perform village-wide and household rituals and festivals, they too spend the summer months in Burang, reading scriptures and performing rituals for households there. Their services are valued due to the shortage of monks - and the tight control of those who remain in Burang's monasteries - as a result of China's highly restrictive policies, and the intensified surveillance and control on religious institutions and activities that have again been in place in Tibet since widespread protests in 2008. Though they must cross the border in plainclothes, once in Burang, Limi monks are able to make a healthy income doing this religious work in private households.

Community members estimated that, of Limiwas working in Burang, $60-70 \%$ make their incomes from wage labour while the remaining $30-40 \%$ engage in trade, such as selling medicinal herbs, saddles, silverware, watches, and wooden bowls, a traditional craft in Limi. Made from maple, pine, and birch burls, Limi bowls are well known across the Tibetan plateau and fetch a handsome price: in 2016, a large maple bowl sold for as much as 1500 USD. Once a local industry, the production of Limi bowls is now thoroughly transnational, and provides another illustration of how Limi livelihoods are dependent on the crossing of multiple 
international borders. As maple trees were depleted in the Limi Valley, Limiwas have since the 1970s gathered burls from other districts of Nepal as well as in India's Himachal Pradesh and Uttarkhand states (Goldstein 1974). The introduction of community forestry and other conservation programs in Nepal and India have made it risky to collect burls, which are now often procured through bribes or simply taken illegally, sometimes resulting in heavy fines or imprisonment. After collection, Limiwas bring them to a woodworking factory in Saharanpur, India, or to Kathmandu, where they are shaped and sanded. Silverwork is done in Kathmandu, followed by painting and varnishing before sales in Burang. Though not without its anxieties (Hausner and Sharma 2013), crossing the Nepal-India border is relatively easy for Limiwas due to the open border policy, which greatly facilitates the wooden bowl trade as well as Limiwas' other sojourns to India during winter months for religious pilgrimage and to visit children in boarding schools there. ${ }^{2}$

\section{Border citizenship}

Limiwas' ability to travel to Burang for work and trade is today based on their possession of an 'Entry-Exit Pass Card for Nepal China Border's Citizen.' Also referred to as a 'border citizen card,' this document was first issued in 2002. Its creation built upon the agreement in place since 1956 by which people living within 30 kilometres of the border can cross to within 30 kilometres on the other side without a passport or visa. As such, the documents simultaneously represent an official recognition of de facto citizenship enacted 'from below' that is, the continuing everyday practices of cross-border mobility despite officials' desires to curtail such movement - and a way to bring these more closely into the purview of state regulation (Shneiderman 2013). Sara Shneiderman $(2013,26)$ argues that the existence of this 
legally recognized category of border citizen provides 'a compelling example of how states may act to create alternative categories of citizenship that recognize and regularize "blurred membership" (Sadiq 2009) rather than always erecting exclusionary borders that define the boundaries of legitimate citizenship as allegiance to a single state.' That is, it illustrates overlapping state sovereignties in a non-postcolonial context that stands in sharp contrast to more frequently studied borders in South Asia.

The category of border citizenship itself is neither static through time nor uniform across space, and within it there are differentiated forms of citizenship - exceptions within exceptions. For example, residents of Mustang, another borderland community with longstanding historical ties to Tibet, are denied the ability to apply for and receive the document, despite also living within 30 kilometres of the border. This is due to the fact that Mustang was the primary base for the Tibetan guerrilla resistance movement, Chushi Gangdruk, from 1960-1974, as well as the fact that the $17^{\text {th }}$ Karmapa escaped from Tibet to exile in India through Mustang in 1999 (Murton 2017a). Similarly, despite the bilateral agreement, the same border citizenship is not afforded to Tibetans on the north side of the border from Limi, due to the Chinese state's restrictions on Tibetan mobilities, particularly its increasingly harsh measures to prevent Tibetans from seeking exile in India. A billboard on the Chinese side of the Hilsa border crossing proclaims in Chinese and Tibetan, 'Strike Hard against illegal secret entry and exit!'

Unlike non-border Nepali citizens, who must use the official border crossing at Hilsa, Humla residents with an 'Entry Exit Pass Card' use a separate border entrance at the adjacent Tibetan village of Sher. Even among these Nepalese border citizens of Humla District, all of whom use an Entry Exit Pass Card, there is sometimes differentiation in cross-border movement based on identity. Limiwas are generally preferred on the local labour market given their ability 
to speak Tibetan. In 2015, non-Limi border citizens were required to leave a substantial deposit at the border, purportedly due to several incidents of theft, but Limiwas were exempt from this rule. Moreover, Limiwas were allowed to labour in villages within the 30-kilometer limit, whereas most other border residents were confined to work in the town of Burang.

Limiwas' abilities to benefit from their Tibetan-ness contrasts with other places such as Mustang where the perceived proximity to Tibetan culture and identity is a liability that limits residents' abilities to use the border as a resource (Murton 2017a). This is in part due to the fact that, though Tibetans seeking exile do pass through Limi, it is not the site of a refugee settlement. Thus, within a larger context in which new Chinese economic networks are dominating crossborder trade, cutting out many former traders (Harris 2013), Limiwas have been able to use their knowledge of Tibetan language and even their Tibetan Buddhist ritual skills (in the case of monks) to their advantage in the labour market. Ironically, Limiwas' growing economic dependence on China thus rewards their cultural Tibetan-ness, even as expressions of Tibetan cultural identity by PRC citizens are increasingly repressed.

The growing economic dependence of the Limi community on China is attested to by the fact that in the summer of 2016, roughly 150 out of an adult population of 500 in Waltse spent the summer working in Burang, about half of them women. It can also be seen in the products that are consumed in Limi. Flour, brick tea, beer, cold beverages, cooking oil, butter, clothing, shoes, and electronics are all brought in from Burang. As of 2016, there were three motorized vehicles in the valley, all with Chinese license plates. Given the absence of a motorable road to the rest of Nepal, the Limi community, with assistance from other residents of upper Humla, obtained funding to turn the former caravan route over the old border crossing at Lapcha Shar into a (somewhat) motorable road that connects Tibet to the village of Dzang and, as of 2019, 
also Waltse. By developing strategic relationships with government officials in Burang, Limiwas have also been able to arrange permission to transport fuel, food, and other goods across the border into Limi via the Lapcha Shar pass, despite the fact that it is not an official border crossing. With Chinese police accompanying them, they are now able to bring goods purchased from Burang by road to Limi, rather than having to walk from Hilsa.

As one Limiwa described it, 'in the past $98 \%$ of our livelihoods came from Humla, but now because Nepal is poor, we are 95\% dependent on Burang.' They are keenly aware that, as one put it, 'the world has turned around.' Community leaders and traders alike speak highly of the Chinese government and its policies for enabling their livelihoods. Whereas Tibetans living in the TAR have highly conflicted responses to state development projects (Yeh 2013), Limi residents observe that the Chinese state gives the people of Burang significant aid and that 'with Burang improving, now we can develop too.'

\section{Sovereignty beyond borders}

To obtain the border citizenship card, Limiwas must travel to the Humla district capital of Simikot and present evidence of citizenship in Nepal. ${ }^{3}$ As Shneiderman (2013) notes, the 2002 introduction of these cards provided an important incentive for many border residents, who previously did not possess identity cards, to finally formalize and 'make' their Nepali citizenship. Obtaining documentation of citizenship, the sine qua non of the modern territorial state, brings the citizen into legible view of the state. Westphalian sovereignty, after all, goes hand in hand with the identification of citizenship with residence in a particular territorial space (Agnew 1994). Yet the purpose of making Nepali citizenship is precisely to enjoy an exceptional form of it border citizenship - the origins of which are in everyday practices 'from below' that precede the 
border itself. Limiwas need to appear in person in Simikot only once; subsequent annual renewals can be done by proxy, with one person generally bringing many people's cards to renew at once. This then enables them, unlike most other Nepali citizens, to spend six months, or even more, of the year earning income in Burang. Thus the process of obtaining the card simultaneously exerts state sovereignty while blurring it.

New Nepalese citizenship documentation notwithstanding, the Nepalese state is not experienced in the Limi Valley as a permanent presence. Most dispute resolution happens within the villages rather than being taken to Nepali courts, a point to which I return below. Throughout the entire Limi Valley, there is only a single police station, which is located between the villages of Dzang and Waltse. It is in theory a border checkpoint, though it is quite distant from the border. Its officers leave in October, returning only in March, to avoid being in the valley when it is cold and closed off from the rest of Nepal. In their meetings with Chinese government officials, Limi villagers reported that these Nepalese border guards were poorly clothed and fed, leading the Chinese state to give food, clothing, and other supplies to the Nepalese guards, further underscoring the weakness of Nepali state presence.

Though there are small Nepali government-run primary schools in the valley, villagers see them as ineffective and problematic because they do not teach Tibetan, and also because, as Dzang Village leaders explained, 'the teachers just come for a few days, eat until they're full, and then leave,' or as another villager explained, 'the teachers are paid seven months' of salary but only stay in the village school for seven days.' Thus, they are quite poorly attended. In the 1990s, Limi households preferred to keep their children at home helping with agropastoral labour. Since then, however, Limi households have become much more closely tied educationally to the Tibetan government-in-exile in India. With the tightened restrictions that have cut off the flow of 
new refugees from Tibet, along with the large-scale migration of South Asian Tibetan exiles to North America, the decline of birthrates of Tibetan exiles, and the request of Drikung Kyabgon Chetsang Rinpoche, the head of the Drikung Kagyu school of Tibetan Buddhism, on behalf of a number of Himalayan communities, the Dharamsala-based Central Tibetan Administration (CTA, the official name of the government-in-exile) has opened its schools to culturally Tibetan peoples of the Himalayas, including Limi, for free. ${ }^{4}$ As a result, many Limi children now attend one of several CTA-run boarding schools, including in Dharamsala and Mussoorie, India, as well as in Kathmandu. In 2016, Dzang village leaders stated that out of roughly 175 children, 100 were in Tibetan exile schools in India, 50 were studying in Kathmandu and the remaining younger 25 were in the small Nepali government run primary schools in the valley. Though some of the non-Tibetan schools in Kathmandu are considered desirable for teaching Nepali in addition to Tibetan and English, it is difficult to pass up the free education offered by exile schools. As a result, both parents and the children who attend the schools feel indebted to the CTA.

The Chinese Party-state views the CTA as a threat to its territorial sovereignty and engages in significant diplomatic efforts to prevent leaders of other countries from meeting with either the $14^{\text {th }}$ Dalai Lama, who has immense moral and religious authority but no longer has a formal political role, or CTA officials. Limiwas' strong integration into the Chinese economy in Burang has sharpened their experience of Chinese state sovereignty. The availability of Tibetan education in exile schools puts Limi community members in a potentially precarious situation. Indeed, the CTA offered to support them in a quest for their own (Tibetan) school in the valley, but Limiwas considered this too risky and turned down the generous offer. Limiwas also reported that in Burang, the Chinese government does not allow them to take phone calls from India, where many of their children are studying. If they do receive such calls, 'officials will 
come and educate you' not to do so again. A ward member from Til explained, in an echo of a frequently heard Tibetan phrase, 'the Chinese are very suspicious' and thus worry that students who have attended CTA schools may work for the CTA after graduation.

The reach of the Chinese state is also evident in Hilsa, where Nepali policemen are pressured to capture and hand over Tibetans who have fled over the border, and have been offered rewards of free pilgrimage to Mount Kailash and Lake Manasarovar, both paramount religious sites for Hindus, as an enticement for doing so. Ordinary Humla residents including Limiwas have also been offered incentives to hand over Tibetans passing through on their way to seek refuge in India. Limiwas meet with Chinese officials in Burang as well as in Limi, where the officials ask them what assistance they need, and generally provide it, whether permission to bring goods or bulldozers into Nepal through Lapcha Shar; cement, wheat, and rice; or better supplies for Nepalese border guards. At the same time, Limiwas have been explicitly warned that they will no longer be permitted to do business or labour in Burang if they guide or shelter Tibetans seeking exile. While the government of Nepal 'territorializes state space through development,' the Chinese state is increasingly providing an alternative source of development that territorializes by placing increasing restrictions on Tibetan exile populations living within Nepal (Murton, Lord, and Beazley 2016, 411).

In Limi, development is experienced today as coming primarily from China rather than Nepal. Rather than having their actions curtailed by the Nepalese state due to pressure from China, as is the case with Tibetan exiles, Limiwas have in some cases taken the Chinese state's concerns into account in governing themselves. For example, a monk from Dzang monastery described to me how the monks hid a photograph of the $14^{\text {th }}$ Dalai Lama usually prominently displayed in the monastery, when Chinese officials came to visit, fearing that it could jeopardize 
Chinese aid or their ability to work in Burang. The ban on display of photographs of the $14^{\text {th }}$ Dalai Lama, who is frequently vilified by the Chinese Party-state for attempting to 'split the [Chinese] motherland,' in Tibetan areas is itself an extra-legal measure in China which is unwritten yet widely enforced, and which does not apply to ethnically Han regions (Barnett 2013). This example demonstrates how Chinese sovereignty extends beyond the territorial extent of the state, understood in Westphalian terms, to shape and constrain the actions of Limiwas in their home valley. The glow of the Chinese state is in some ways felt more strongly than that of Nepal, despite their official citizenship status.

Yet the overlap of sovereignties in the Limi valley is not limited to that of states. After all, the monks in Dzang replaced the photograph of the $14^{\text {th }}$ Dalai Lama as soon as the Chinese official left. The $14^{\text {th }}$ Dalai Lama's immense moral and religious authority can be understood, in Latham's $(2000,7)$ terms as the ability to place actions and practices into a sovereign 'system of meaning, significance, institutionalization, and power.' It also remains the basis for what McConnell (2009) calls the 'de facto sovereignty' of the Tibetan government-in-exile. While the CTA does not collect taxes from, or claim to represent Himalayan communities such as Limi in the way that it does Tibetan exiles, its provision of free schooling suggests a state-like function. Moreover, a key pedagogical function of exile schools is to inculcate in its students a Tibetan national identity and the mythico-history of a once and future independent Tibet (Yeh 2007), thus creating another 'distant glow' of a non-state form of sovereignty.

\section{Social sovereignty of the Limi community}

However, the most immediate and pervasive source of power that shapes, regulates, and constrains the lived experience of Limiwas across the state boundaries of Nepal, China, and India 
is the social sovereignty of the community itself. The locus of this power is not today vested in the singular agency of a local religious or secular leader, but rather is constituted by an elaborate set of laws (khrims), which include requirements to fulfil taxes, follow contracts, provide sons to the monastery, and be present in Limi at certain times of the year. That is, Limi is a site of legal pluralism, where "law and legal institutions are not subsumable within one "system" but have their sources in the self-regulatory activities which may support, complement, ignore or frustrate one another' (Griffiths 1986, 1). While they might also be called 'rules' or 'regulations,' Limiwas refer to them with the Tibetan term for law, khrims, and the literature on legal pluralism cautions against taking for granted 'the power to name one "form of social ordering" law and name some other form of social ordering a lesser category' (Robinson and Graham 2018, 4, citing Santos 2002, 91).

Indeed, villagers explicitly see community and Nepali law as being of equal importance, rather than the former being subordinate to the latter. One man from Dzang explained, 'half of our laws are not the Nepali state's laws. Half are. The other half are the laws of our own place.' As an example, he pointed to the differential requirements for provision of communal labour among the three categories of households: 'according to the Nepalese government's laws, everyone should provide an equal share, but in the village we follow our own laws.'

Included among these are village laws that govern agriculture, land, and water; those that function to maintain and reproduce monastic institutions; and practices and rules related to the governance of the community. The former include stipulations regarding the consultation of the Tibetan almanac to determine dates for planting and harvesting of grain, which must be done by all on the same day; the frequency and timing of irrigation; rotational grazing; the prohibition against letting livestock onto the fields until after hay is harvested; and a prohibition on loud 
shouting during the growing season. Regulations that could be considered environmental in orientation are similar to those found in other Nepal-Tibet border communities (e.g. Childs and Choedup 2018), and include a prohibition on hunting, on washing in springs, setting fire in the forest, and wanton picking of plants (harvest of recognized medicinal herbs is acceptable).

Laws that support the continuation of Rinchenling Monastery include taxes to provide butter and grain to the monastery, particularly by households with monk members; the requirement that a quorum of thirteen monks must be in residence at the monastery for the entirety of the seven-month ritual calendar; and the monk levy. Some current taxes are adaptations of former taxes paid to Tibet until 1959, and taxes to the Nepali state, paid until the Maoist insurgency at the end of the 1990s (Hovden 2016, 164-65). For example, villagers decided to keep collecting the butter tax that was previously sent to a monastery in Tibet, using it for Rinchenling's butter lamps instead (ibid). Taxes paid to Nepal were relatively small and have been used for village funds. The majority of taxes, however, are collected by the village assembly and by the monastery, for different religious purposes (Hovden 2016).

Collection of village taxes and enforcement of village laws is carried out by the village assembly, which is constituted by the male heads of all large and small households. These household representatives must participate in communal labour at specified times, and be present at conflict resolution meetings and village assembly meetings, regardless of whether they are residing in Burang, Kathmandu, or elsewhere; otherwise, they must pay a fine. As in other Himalayan borderland communities (Childs and Choedup 2018; Ramble 2008), Limiwas have a formal retirement age (in their case, sixty-five) at which time they are no longer allowed to attend assemblies. Upon retirement, the household's relevant son must return to the village to 
take up his position as household head, even if he is still in school, as long as he has reached the age of fifteen.

Some of the laws governing the village have been in place since before 1959, but others are new, created in response to changing circumstances. The village assembly is referred to as the 'government' or zhung, and functions as the government body that deliberates upon and creates new laws. Since the 1990s, new laws have been created to call sons and daughters back from school to the village, and to keep monks in local monasteries (Hovden 2016, 112). In 2016, Limiwas stated they had recently enacted a new law prohibiting the cutting of live trees for private housing after a significant amount of timber was used to build new community halls.

These legal decisions are recorded in the village archive, which also includes the tax register and contracts written after dispute resolution (Hovden 2016). Villagers, including leaders, are forbidden to view these except during village assemblies. If informal mediation cannot resolve conflicts that arise in the village, three levels of appeal are used, starting with a decision by the village assembly, which can be appealed to a 'court of fifteen,' a procedure established in 2001, followed if that fails as well by a three-village meeting (Hovden 2016, 142-3). Only in the rare cases where all three levels of appeal fail are disputes taken to Nepali government officials.

This body of institutionalized laws, codes, and relations that constitutes social sovereignty in Limi is not static, but rather has emerged over time in relation to shifting external authority. Historically, hereditary leaders made decisions, settled local disputes, and wrote and kept village legal documents, while also dealing with Nepali and Tibetan authorities (Hovden 2016). The harsh repression and breakdown of traditional institutions in Tibet after 1959 led these leaders to 'develop a strategy for managing as much as possible of the decision-making and conflict-resolution internally' (126). After the introduction of the panchayat system in Nepal in 
the 1960s, the Tibetan leaders were simply given new Nepali titles. In 1991, Nepal's introduction of the Village Development Committee system ended hereditary leadership (ibid). In its place, Limi villagers decided to choose leaders by lottery, on a rotational basis. An older villager described the transition as smooth because 'everybody knows the village laws' (Hovden 2016, 131). Indeed, Hovden writes that 'the villages are so thoroughly regulated by laws that efficient internal management is relatively independent of leadership skills' (Hovden 2016, 132). Whereas hereditary leaders were once the agents of social sovereignty, today it is the entire village assembly that reproduces and adheres to these laws and codes.

The strictness with which Limiwas follow their community laws surprises even observers from nearby culturally Tibetan borderland communities in upper Humla. A former primary school teacher in Limi, from Kermi village in a neighbouring valley, pointed out that unlike in his home village, where respect for the resident reincarnate lama is paramount, Limi villagers respect above all their local laws despite the absence of a strong single leader to enforce them. Limiwas' use of the term 'government' to refer to the village assembly further demonstrates the force of the community's social sovereignty.

However, these structures are now encountering new challenges in the form of permanent outmigration. The three villages have responded quite differently to households who wish to permanently withdraw from the community. Permanent outmigration from Dzang and Til began in the early 2000s with a small number of wealthy households who wished to settle in Kathmandu to do business. These households made donations to the villages, and because there were still many monks to rotate into the quorum of thirteen per year, they were allowed to exit without objection. 
By 2018, however, the trickle was threatening to become a flood, leading to the enactment of new rules as well as significant controversy. Poorer households had also begun to want to leave, and because wealthier households had already left, trying to block them was seen as unfair. Households who exit from Til are allowed to rent or sell their farmland, though there are few takers. In Dzang, the village takes ownership of the best farmland, dividing it amongst households who remain. In neither case, though, do Nepalese state-recognized land titles change; these are simply seen as irrelevant. New rules also stipulate that households who exit can no longer access community grasslands or forests without paying a fee.

The most pressing issue for households who decide to abandon the community rather than continue to be subject to its sovereignty is the monk levy. Monks from Dzang and Til now live not only in Kathmandu and India, but also in the US, Switzerland, and France. In the winter of 2015-16, there were not enough monks residing in Dzang to perform the rituals, leading to the closure of the monastery. This dire situation led the village assembly to call a comprehensive meeting in late 2016 for all monks as well as households; a fine was set at 75,000 Nepali Rupees (more than 700 USD) per day for not showing up, compelling attendance of those residing overseas. In the lead-up to the meeting, there were discussions of levying exorbitant fines on monks who did not fulfil their duties. In the end, however, it was decided that only five monks (down from the previous thirteen) must remain in the monastery for the duration of the ritual calendar. For this, they were each to be compensated 200,000 Nepali Rupees per year, ${ }^{5}$ raised through donations from organizations in Kathmandu.

This system was in place for two years, but did not satisfy the monks who remained in Dzang. While five monks received some salary, four additional monks received no compensation and yet participated as before in all rituals and monastic duties. This unsatisfactory situation led 
the monks to decide that they would no longer accept the salary for five monks. Instead, either the monastery would close, or the village should return to a quota of thirteen monks. A new meeting was called during which the monks delivered this ultimatum. Villagers requested that they be allowed to pay heavy fines in lieu of supplying their sons, but the monks refused. In the end, the community agreed to the new rule. Yet because many households with eligible monks no longer wish to send their sons to fulfil their duties, this led to large-scale permanent exit amongst households from the village. By 2019, there were only 27 households residing in Til, as compared to 36 in 2016; out of Dzang's 65 households, only 35 remained. Expressing the quandary that many felt, one household head explained that he had voted in favour of the new law as he could not abide by the thought of closing the monastery, and yet he himself was also planning to withdraw from the village because of an inability to adhere to it.

Waltse, however, has taken a very different path, both because of the immense significance of Rinchenling Monastery, and because no one had sought to exit until relatively recently. Villagers of Waltse fear that if their strict laws were to falter, the monastery would 'become empty.' Nobody is willing to bear the burden of responsibility for causing the monastic institution to collapse. Because of the intense desire to avoid the religious demerit and potential loss of fortune from the closure of the monastery, and because they have witnessed what has happened in Dzang and Til, the village has enacted very strict rules forbidding outmigration. The village has ruled that it will confiscate not only all of a household's farmland, but also its house and movable and immovable property. Thus, as of 2019, only one of Waltse's 96 households had exited the village. The required quorum of 13 monks continues to reside in the monastery and perform all rituals for the ritual calendar. 
During the multiple controversies in Dzang, those opposed argued that the new measures were against Nepali state law, according to which citizens of the country cannot be compelled to stay in a village. Several older Limiwas who have settled permanently in Kathmandu animatedly complained to me about the fact that Limi village laws defy Nepali state law. Describing villagers who thought otherwise as 'backwards,' 'having old brains,' and not knowing how the world works, they pointed out that the Nepali state's legal apparatus does not permit requiring families to send children to become monks, compelling male children to give up schooling when their fathers reach a certain age, or making monks stay in a village during the winter. Limiwas, they said, must pay more attention to complying with Nepali law.

These arguments are taken up by Limiwas, young and old, who reside outside the valley, as well as by those who wish to leave. A representative of the Limi Youth Association in Kathmandu stated that villagers should keep their good village laws, particularly those related to environmental protection, while abandoning old ones, which prevent much needed development. The critiques are particularly directed at Waltse villagers, whom the others criticized for their 'old brains,' their purported lack of ability, and their backwardness. They point, for example, to a young man from Waltse who received a coveted scholarship to study in France, and yet had to give it up to return to the village to take up the role of head of household. A Waltse village leader, however, criticized the decisions of the two other villages, stating that they are 'bad for the future' for allowing the monasteries to falter and rituals generating collective fortune to go unperformed. Both sides make temporal arguments ('old' brains vs. concerns about the future), but only those who wish to stop following the strict village regulations claim that Nepali state laws must supersede community laws. In making these arguments, these erstwhile Limiwas effectively argue against the legal pluralism that has long characterized their borderland home. By couching 
their objections in terms of the more encompassing authority of state law, they implicitly also argue against the social sovereignty of the village, the body of relations that currently shapes spheres of social life across state boundaries, foreshadowing and helping to bring about a likely future in which the Nepali state's sovereignty is a more permanent presence, rather than a 'distant glow.'

Ironically, some of those seeking to assert that the Nepali state's sovereignty over the full extent of its territory should override the community's social sovereignty, do so in order to leave Nepal. Though some who make this argument reside in Kathmandu, others seek to continue schooling in India, provided by the government-in-exile and its sponsors; or to move to the West. In other words, whereas states typically exert their sovereign power in borderlands by constricting mobility, here Limi villagers see their selective invocation of state sovereignty through its laws as enabling greater transnational mobility.

\section{Conclusion}

In statist terms, both the land and people of the Limi Valley now belong firmly to Nepal. However, to think of Nepal's international boundaries as a container for Limiwas and their social relations would be a profound mistake. Though the demarcation of the border in the early 1960s led to economic decline, political-economic transformations in China over the past several decades together with their border citizenship have enabled Limiwas to use the border as a resource to maintain their livelihoods as well as the village taxes and laws that constitute their social sovereignty. Their increasing economic dependence on China ironically draws on their Tibetan-ness through the advantages that Limiwas have on the Burang labour market. At the same time, it also constrains Limiwas, for example preventing them from communicating by 
phone with their children attending Tibetan government-in-exile schools. Thus even as Limiwas' status as exceptional border citizens can be seen as a strong manifestation of blurred citizenship 'from below,' it simultaneously brings them into the purview of Chinese state sovereignty.

However, these overlapping sovereignties only partially account for authority and power over everyday life. The social sovereignty of the community, referred to as a 'government' with a set of laws that are not subordinate to those of the Nepalese state, governs land, taxation, and decisions about mobility and residence. For many Waltse villagers, it remains utterly unthinkable to allow Rinchenling Monastery to 'become empty,' a situation that requires strict adherence to village laws to prevent. However, recent outmigration from Til and Dzang poses a threat to village integrity. A significant tension has emerged between those who remain translocally connected to and committed to the reproduction of the Limi community, returning to fulfil their obligations to the village and monastery, and those whose new journeys may now entail a severing of these constitutive ties. Significantly, these tensions have been articulated in terms of a conflict between community and state law. Those seeking to leave deploy the idiom of statist law, the dominant horizon for contemporary political imaginations, arguing that Limiwas who remain attached to place must nevertheless give way to the higher authority of the Nepali state. Rather than refusing state sovereignty, they seek to bolster it to increase their own mobility.

Faced with this difficult situation, Limiwas who remain in the valley are now counting on the completion of motorable roads connecting them to the rest of Nepal and to the PRC, in the hopes that these will bring tourists, and with them donations and sponsors for Rinchenling Monastery. New (foreign) sponsors, they feel, would provide the resources necessary to keep the monastery running and could thus potentially enable the corporate community to change its current levies and laws, that is, to transform social sovereignty even while maintaining it. 
Limiwas also believe that new roads that make transportation in and out of the valley faster and easier, in conjunction with new income opportunities for tourism, could entice more members of the younger generation to return to Limi, and make living there less of a burden for those who take up the position of head of household. In other words, more mobility for others will, they hope, allow them to maintain a framework of social sovereignty, even as they continue to negotiate multiple other sovereignties. Without romanticizing social sovereignty in Limi, which is indeed experienced by many as conservative and burdensome, it usefully illuminates how nonpostcolonial borderlands can be far more than zones of lawlessness and bare life.

\section{References}

Agamben, G. 1998. Homo sacer: Sovereign power and bare life. Redwood City: Stanford University Press.

Agnew, J. 1994. The territorial trap: The geographical assumptions of international relations theory. Review of International Political Economy 1(1): 53-80.

Agnew, J. 2005. Sovereignty regimes: Territoriality and state authority in contemporary world politics. Annals of the Association of American Geographers 95: 437-61.

Barnett, R. 2013. Restrictions and their anomalies: The Third Forum and the regulation of religion in Tibet. Journal of Current Chinese Affairs 41(4): 45-107.

Bauer, K. 2004. High frontiers: Dolpo and the changing world of Himalayan pastoralists. New York: Columbia University Press.

Bishop, B. 1990. Karnali under stress: Livelihood strategies and seasonal rhythms in a changing Nepal Himalaya. Chicago: University of Chicago Geography Research Papers no. 228-29. 
Butler, J. 2004. Precarious life: The powers of mourning and violence. New York: Verso.

Chan, Y. W., and B. Womack. 2016. Not merely a border: Borderland governance, development and transborder relations in Asia. Asian Anthropology 15(2): 95-103.

Childs, G., and N. Choedup. 2018. From a trickle to a torrent: Education, migration, and social change in a Himalayan valley of Nepal. Berkeley: University of California Press.

Cons, J. 2016. Sensitive space: Fragmented territory at the India-Bangladesh border. Seattle: University of Washington Press.

Cunningham, H., and J. Heyman. 2004. Introduction: mobilities and enclosures at borders. Identities 11(3): 289-302.

Dean, K. 2018. Borders and bordering in Asia. In Routledge handbook of Asian borderlands, ed. A. Horstmann, M. Saxer, and A. Rippa, 56-72. New York: Routledge.

Des Chene, M. 2007. Is Nepal in South Asia? The condition of non-postcoloniality. Studies in Nepali History and Society 12(2): 207-23.

Dunn, E., and J. Cons. 2014. Aleatory sovereignty and the rule of sensitive spaces. Antipode. 46(1): 92-109.

Gellner, D. 2013. Northern South Asia's diverse borders, from Kachchh to Mizoram. In Borderland lives in northern South Asia, ed. D. Gellner, 1-23. Durham: Duke University Press.

Fürer-Haimendorf, C.v. 1975. Himalayan traders. New York: St. Martin's Press.

Gautam, Y., and P. Anderson. 2016. Rural livelihood diversification and household well-being: Insights from Humla, Nepal. Journal of Rural Studies 44: 239-49.

Gazit, N., and R. Latham. 2014. Spatial alternatives and counter-sovereignties in Israel/Palestine. International Political Sociology 8: 63-81. 
Goldstein, M. 1974. Tibetan speaking agro-pastoralists of Limi: A cultural ecological overview of high altitude adaptation in the Northwest Himalaya. Objets et Mondes 4: 259-68.

Goldstein, M. 1975. A report on the Limi Panchayat, Humla District, Karnali Zone. Contributions to Nepalese Studies 2(2): 89-101.

Griffiths, J. 1986. What is legal pluralism? Journal of Legal Pluralism 24: 1-39.

Hansen, T. B., and F. Stepputat. 2006. Sovereignty revisited. Annual Review of Anthropology 35: $295-315$.

Harris, T. 2013. Trading places: New economic geographies across Himalayan borderlands. Political Geography 35: 60-68.

Hausner, S., and J. R. Sharma. 2013. On the way to India: Nepali rituals of border crossing. In Borderland lives in northern South Asia, ed. D. Gellner, 94-116. Durham: Duke University Press.

Hovden, A. 2013. Who were the sponsors? Reflections on recruitment and ritual economy in three Himalayan village monasteries. In Tibetans who escaped the historian's net: Studies in the social history of Tibetan-speaking societies, ed. C. Ramble, P. Schwieger, and A. Travers, 209-32. Kathmandu: Vajra Books.

Hovden, A. 2016. Between village and monastery: A historical ethnography of a Tibetan Buddhist community in north-western Nepal. PhD diss., University of Oslo.

Jones, R. 2009. Agents of exception: Border security and the marginalization of Muslims in India. Environment and Planning D: Society and Space 27: 879-97.

Jones, R. 2012. Spaces of refusal: Rethinking sovereign power and resistance at the border. Annals of the Association of American Geographers 102(3): 685-99. 
Korf, B., and T. Raeymaekers. 2013. Introduction: Border, frontier, and the geography of rule at the margins of the state. In Violence on the margins: States, conflict and borderlands, ed. B. Korf and T. Raeymaekers, 3-28. New York: Palgrave Macmillan.

Korf, B., T. Raeymaekers, C. Schetter, and M. J. Watts. 2018. Geographies of limited statehood. In The Oxford handbook of governance, ed. A. Draude, T. A. Börzel, and T. Risse. (26 pages) DOI: 10.1093/oxfordhb/9780198797203.013.8. Oxford: Oxford University Press.

Latham, R. 2000. Social sovereignty. Theory, Culture and Society 17(4): 1-18.

Massey, D. 1991. A global sense of place. Marxism Today 38: 24-29.

McConnell, F. 2009. De facto, displaced, tacit: The sovereign articulations of the Tibetan government-in exile. Political Geography 28(6): 343-52.

McConnell, F. 2010. The fallacy and the promise of the territorial trap: Sovereign articulations of geopolitical anomalies. Geopolitics 15(4): 762-68.

Megoran, N. 2006. For ethnography in political geography: Experiencing and re-imagining Ferghana Valley boundary closures. Political Geography 25: 622-40.

Moore, D. 2005. Suffering for territory: Race, place and power in Zimbabwe. Durham: Duke University Press.

Murton, G. 2017a. Border corridors: Roads, trade, aid and geopolitics of state-making between Nepal and China. PhD diss., University of Colorado Boulder.

Murton G. 2017b. Making mountain places into state spaces: Infrastructure, consumption, and territorial practice in a Himalayan borderland. Annals of the American Association of Geographers 107(2): 526-45. 
Murton, G., A. Lord, and R. Beazley. 2016. 'A handshake across the Himalayas': Chinese investment, hydropower development, and state formation in Nepal. Eurasian Geography and Economics 57(3): 403-32.

Ramble, C. 2008. The navel of the demoness: Tibetan Buddhism and civil religion in highland Nepal. Oxford: Oxford University Press.

Reeves, M. 2014. Border work: Spatial lives of the state in rural Central Asia. Ithaca: Cornell University Press.

Robinson, D., and N. Graham. 2018. Legal pluralisms, justice and spatial conflicts: New directions in legal geography. The Geographical Journal 184(1): 3-7.

Ross, J. L. 1983. Adaptation to a changing salt trade: The view from Humla. Contributions to Nepalese Studies 10(1-2): 43-48.

Sadiq, K. 2009. Paper citizens: How illegal immigrants acquire citizenship in developing countries. New York: Oxford University Press.

Santos, B. D. S. 2002. Toward a new legal common sense. Cambridge: Cambridge University Press.

Saxer, M. 2013. Between China and Nepal: Trans-Himalayan trade and the second life of development in upper Humla. Cross-Currents: East Asian History and Culture Review. No. 8. https://cross-currents.berkeley.edu/e-journal/issue-8/saxer.

Saxer, M. 2017. New roads, old trades: Neighbouring China in Nepal. In The art of neighbouring: Making relations across China's borders, eds., M. Saxer and J. Zhang, 7392. Amsterdam: Amsterdam University Press. 
Saxer, M., A. Rippa and A. Horstmann. 2018. Asian borderlands in a global perspective. In Routledge handbook of Asian borderlands, ed. A. Horstmann, M. Saxer, and A. Rippa, 113. New York: Routledge.

Schendel, W.v. 2002. Stateless in South Asia: The making of the Indo-Bangladesh enclaves. The Journal of Asian Studies 61: 115-47.

Shewly, H. 2013. Abandoned spaces and bare life in the enclaves of the India-Bangladesh border. Political Geography 32: 23-31.

Shewly, H. 2015. Citizenship, abandonment and resistance in the India-Bangladesh borderland. Geoforum 67: 14-23.

Shneiderman, S. 2013. Himalayan border citizens: Sovereignty and mobility in the NepalTibetan Autonomous Region (TAR) of China border zone. Political Geography 35:25-36. Spengen, W.v. 2000. Tibetan border worlds: A geohistorical analysis of trade and traders. New York: Kegan Paul International.

Tsing, A. 1993. In the realm of the Diamond Queen: Marginality in an out-of-the-way place. Princeton: Princeton University Press.

Wallrapp, C., H. Faust, and M. Keck. 2019. Production networks and borderlands: Cross-border yarsagumba trade in the Kailash landscape. Journal of Rural Studies 66: 67-76.

Wilson, T., and Donnan, H. 1998. Nation, state and identity at international borders. In Border identities: Nation and state at international frontiers, ed. T. Wilson and H. Donnan, 1-30. Cambridge: Cambridge University Press.

Yeh, E. T. 2007. Exile meets homeland: Politics, performance and authenticity in the Tibetan diaspora. Environment and Planning D: Society and Space 25(4): 648-67. 
Yeh, E.T. 2013. Taming Tibet: Landscape transformation and the gift of Chinese development. Ithaca: Cornell University Press.

Zeller, W. 2013. Get it while you can: Governance between wars in the Uganda-South Sudan borderland. In Violence on the margins: States, conflict and borderlands, ed. B, Korf and T. Raeymaekers, 193-218. New York: Palgrave MacMillan.

\section{Endnotes}

${ }^{1}$ Sagar Lama (Yonten Gyatso) conducted the follow-up interviews in Limi in November 2016 with questions I provided. In 2018, after my submission of the initial version of this paper for review, Astrid Hovden made her 2016 dissertation available to me. It reinforced and deepened my understanding of many facets of what I theorize as Limi's social sovereignty.

${ }^{2}$ Limiwas' relationship with India, and India's assertions of sovereignty in relation to Nepal, are also relevant, but beyond the scope of this paper.

${ }^{3}$ Ironically, there are cases in upper Humla where a close connection with Burang has resulted in households being unable to travel to Burang. In Yari, the father of one household was from Burang and had married in to the village. Because the Nepalese Constitution does not allow citizenship to pass through the mother, the father and children are not Nepalese citizens and thus cannot obtain a border exit-entry card that would allow them to travel to Burang (Phurwa Gurung, pers. comm.)

${ }^{4}$ Some also attended in the past, but to do so they had to pretend to be Tibetan refugees.

${ }^{5}$ In 2016, the average household income for ethnically Lama (culturally Tibetan) households in the Humla district was 268000 Nepali Rupees, or roughly 2400 USD (Gautam and Anderson 2016). 


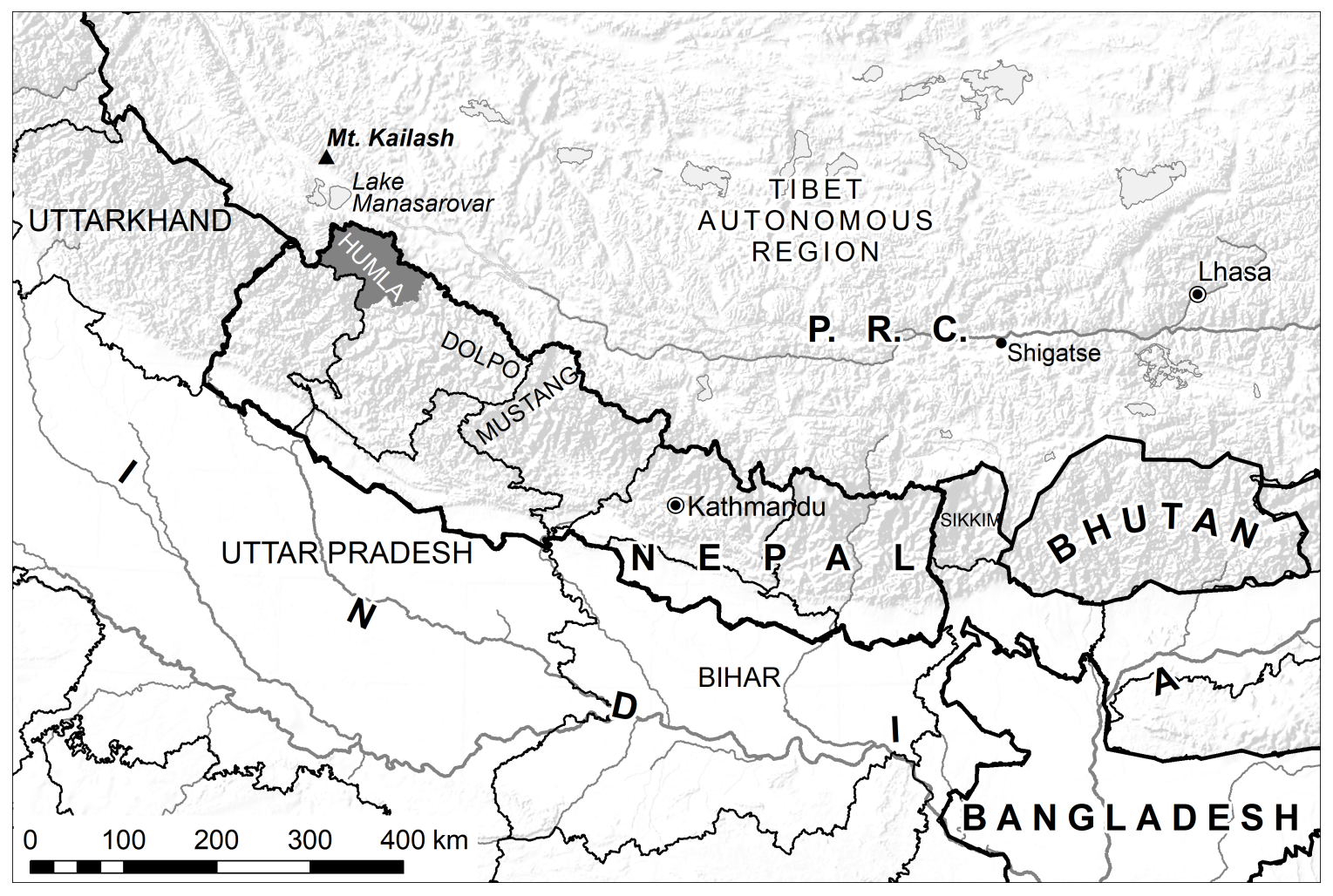




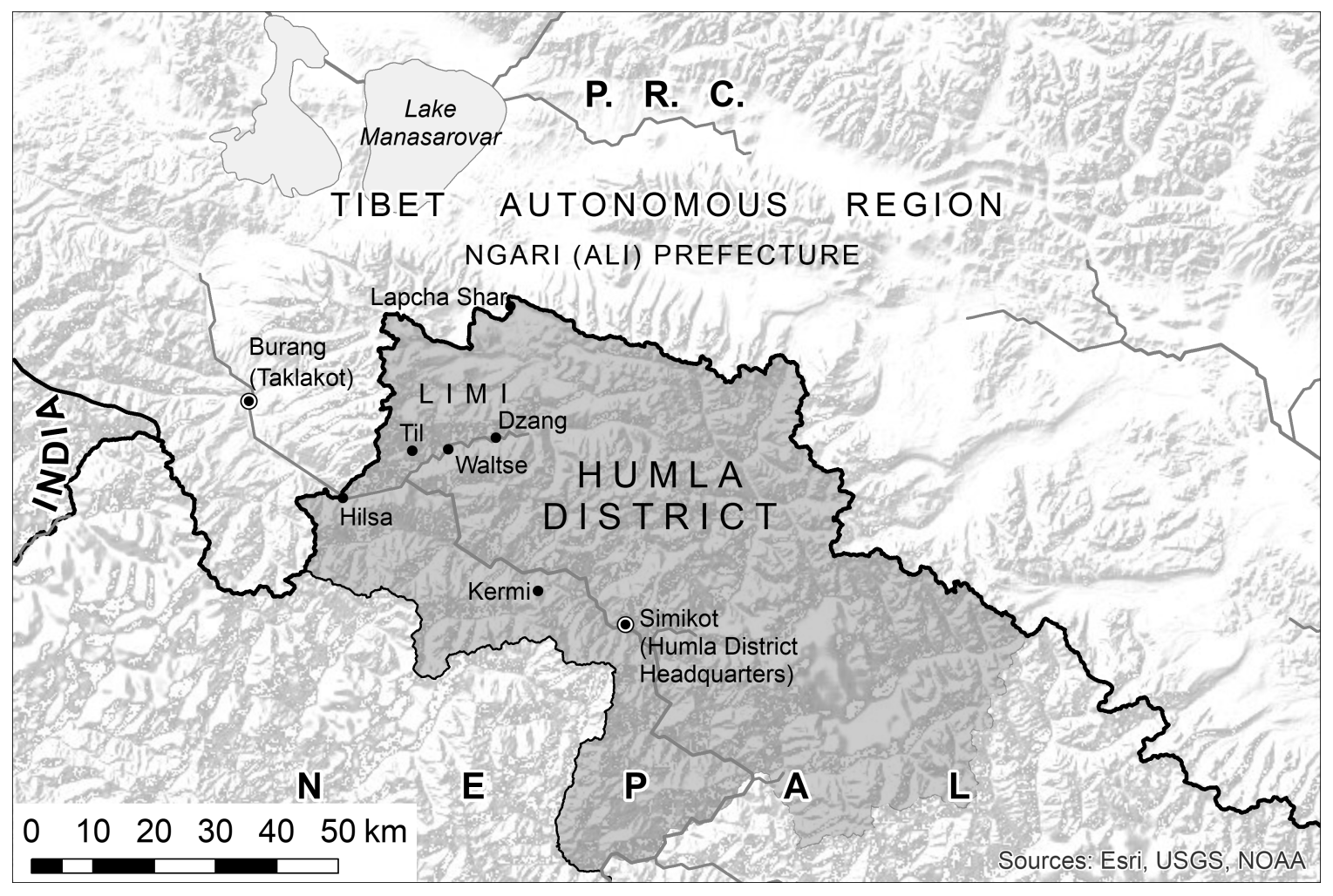

